\title{
DISCUSSION
}

H. Engelhardt: On Blue Glacier only one bore hole which reached the bottom at a subglacial stream responded immediately with a drop in water level. All our other holes but one opened up an interconnecting channel after a few days or several weeks, as indicated by abrupt variations in water level. Did you find on Gornergletscher that the chances to connect a particular bore hole to a major drainage channel are increased as the bore holes are located closer to the channels?

H. Röthlisberger: This question is hard to answer since we can only guess where the channels are located, but as a rule we did find a faster connection to the drainage channels the closer we drilled to existing moulins. Nearer the snout, however, where more water flows at the bed, we obtained connections within one or two days even where no moulins existed in the neighbourhood.

L. A. Lliboutry: We must be careful when speaking of connection or no connection, because the two cases are not clear cut. There may be connection for a discharge of a few centimetres per year of bottom melting, and no connection for a large amount of water coming from surface melting.

G. DE Q. Robin: Is there any evidence that time for connection of bore hole to the main subglacial drainage is a function of thickness of ice, and hence of water-pressure differential at the bottom of the bore hole.

RöTHLisBerger: We had expected that at greater depth it should become easier to establish the connection to the main drainage, but our deepest hole so far did not drain at $330 \mathrm{~m}$ depth (some $50 \mathrm{~m}$ above the bed), even after blasting. Some shallow holes, on the contrary, did drain. We have not yet drilled enough bore holes really to give a final answer to your question.

\section{THE UPLIFT OF UNTERAARGLETSGHER AT THE BEGINNING OF THE MELT SEASON-A CONSEQUENCE OF WATER STORAGE AT THE BED?}

By A. IKen,
(Versuchsanstalt für Wasserbau, Hydrologie und Glaziologie an der Eidgenössischen Technischen Hochschule Zürich, CH-8og2 Zürich, Switzerland)

A. Flotron, (Ingenieurbüro Flotron, Bahnhofstrasse, $\mathrm{CH}-3860$ Meiringen, Switzerland)

W. Haeberli, and H. Röthlisberger

(Versuchsanstalt für Wasserbau, Hydrologie und Glaziologie an der Eidgenössischen Technischen Hochschule Zürich, CH-8og2 Zürich, Switzerland)

Abstract. The results of systematic movement studies carried out by means of an automatic camera on the Unteraargletscher since I969 (Flotron, I973) are discussed together with more recent findings from theodolite measurements made at shorter intervals and over a longer section of the glacier.

In addition to the typical spring/early-summer maximum of velocity known from other glaciers, an upward movement of up to $0.6 \mathrm{~m}$ has been recorded at the beginning of the melt 
season. It was followed, after various fluctuations of the vertical velocity, by a similar but slower downward movement which continued at an almost constant rate for about three months. The uplift was not confined to the section covered by the camera but occurred nearly simultaneously in profiles located $\mathrm{I} \mathrm{km}$ below and $2 \mathrm{~km}$ above. The times of maximum upward velocity (increases of up to $140 \mathrm{~mm} / \mathrm{d}$ ) coincided approximately with periods of large horizontal velocity and occurred after increases of melt-rate.

The following explanations for the variations of vertical velocity are considered: (I) Changes of longitudinal strain-rate. (2) Changes of the sliding velocity in a channel of variable width and with a bed slope deviating from horizontal. (3) Changes of volume due to opening or closing of crevasses. (4) Swelling or contraction of veins at the grain edges. (5) Growth (and closure) of cavities in the interior of the glacier. (6) Changes of large-scale water storage at the bed.

Although all of the mechanisms (I)-(5) have some effect on the vertical ice movement, they cannot account for the observed variations of vertical velocity. We therefore conclude that large-scale water storage at the bed is the main cause of the uplift. Apparently the storage system is efficiently connected with the main subglacial drainage channels only during times of very high water pressure in the channels.

The findings are of some interest to the concepts of glacier sliding: As mentioned above the maxima of horizontal velocity - and thus of the sliding velocity-have not been measured at the time when the storage had attained a maximum, but at the time of maximum vertical velocity, which we assume to be the time of most rapid growth of cavities at the bed. This behaviour of the sliding velocity agrees with that predicted by a simple finite-element model of the basal ice on a wavy bed with water-filled cavities. In particular, the model shows that the sliding velocity is larger during the process of cavity growth than at the final stage when the cavities have grown to the size which is stable for the applied water pressure.

\section{REFERENCE}

Flotron, A. 1973. Photogrammetrische Messung von Gletscherbewegungen mit automatischer Kamera. Vermessung, Photogrammetrie und Kulturtechnik, Jahrg. 71, Ht. 1-73, Fachblatt, p. ${ }_{15}^{-17}$.

\section{DISCUSSION}

M. F. Meier: At first sight, a $0.5 \mathrm{~m}$ uplift of this glacier may appear unusual. But, in Moscow in 197 I we reported on very careful measurements of liquid-water input and output from May to October at South Cascade Glacier. We found a release from storage of $\mathrm{I} \mathrm{m}$ of liquid water averaged over the glacier area. Thus your observations and ours are consistent.

A. Iken: Yes, probably. It would be interesting to observe the vertical movement of South Cascade Glacier at various profiles.

L. A. Lliboutry: Are you sure of your levelling?

IKEN: I do not think that the observed variations of vertical movement can be the result of varying vertical refraction. First, errors due to vertical refraction are usually expected to be in the order of $2^{\mathrm{cc}}$ only if measurements are taken over a distance of $200 \mathrm{~m}$. Secondly, if we expect larger refraction effects at glacier margins, we should also expect diurnal variations of these effects. During the periods of uplift, measurements were taken from two to four times a day, but do not show a diurnal variation. We are therefore confident that the uplift is not a result of varying vertical refraction.

J. W. Glen: In your model some flow vectors at the bed do not seem to be parallel to the bed. Could you comment on the significance of this? 
H. RöthlisBerger: The transient ice flow when a cavity is forming, with the flow vectors pointing away from the rock surface at an angle, looks very promising for providing a process of plucking. Although it is unlikely that the rock will adhere firmly to the ice, there is a possibility that the water pressure might act on the lower side of a scaled-off rock slab, which might then be moved together with the ice.

IKEN: In the following I am referring to the sinusoidal bed of the model: When water under pressure can penetrate from subglacial channels to the lee sides of the bedrock waves, the pressure will be increased at the centres of the lee-sides, thus lowering the pressure-melting temperature there. However, at the edges of the lee sides, i.e. near the wave crests and valleys, the pressure will be abruptly reduced when transient ice flow causing cavity formation starts. In these zones, therefore, rock fragments will freeze to the glacier completing the plucking mechanism which you suggested.

\title{
TRANSIENT WATER FLOW IN SUBGLACIAL GHANNELS
}

\author{
By William St Lawrence
}

(U.S. Army Cold Regions Research and Engineering Laboratory, Hanover, New Hampshire 03755 , U.S.A.)

and ANTHONy QAMAR

(Department of Geology, University of Montana, Missoula, Montana 5980 I, U.S.A.)

Abstract. A hydraulic mechanism is postulated as the source of certain low-frequency $(\mathrm{I}-5 \mathrm{~Hz})$ seismic signals that are recorded in the vicinity of temperate glaciers. To illustrate that the mechanism is a plausible seismic source, the equations of motion and continuity for transient flow in a subglacial conduit are developed. The solution to these equations is obtained for the case of the flow of water being terminated in a glacial conduit. Using reasonable values of physical parameters taken from the literature, the displacement of the conduit walls is determined as a function of time and distance along the tunnel. The spectral character of the proposed source and the period of time over which it operates is compared with seismic records of typical type II signals. The agreement in terms of these parameters is good.

To further examine the validity of the proposed seismic source a preliminary energy calculation is made which demonstrates that the proposed mechanism is energetically reasonable. Evidence of hydraulically generated seismic waves from a dam site is introduced to support the theory of a hydraulic source.

Based on the evidence presented, it is suggested that the flow of water from glaciers is modulated by an internal flow regime that is intermittent in time and space.

The substance of this paper is included in a report by the present authors entitled "Hydraulic transients: a seismic source in volcanoes and glaciers", published in Science, Vol. 203 , No. $43^{8}$ i, 1979, p. $654^{-56}$. 